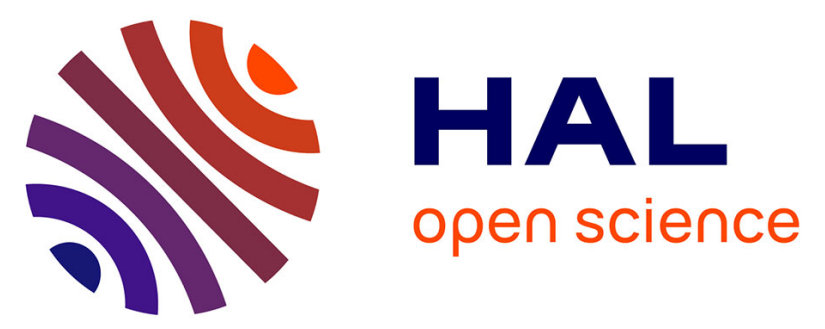

\title{
Effects of two wheat cultivars on physico-chemical properties of wheat flours and digesta from two broiler chicken lines (D+ and D-) differing in digestion capacity.
}

Alexandre Péron, Birger Svihus, Irène Gabriel, Serge Bérot, Daniel Tanguy, Brigitte Bouchet, Joëlle Gomez, Bernard Carré

\section{To cite this version:}

Alexandre Péron, Birger Svihus, Irène Gabriel, Serge Bérot, Daniel Tanguy, et al.. Effects of two wheat cultivars on physico-chemical properties of wheat flours and digesta from two broiler chicken lines (D+ and D-) differing in digestion capacity.. British Poultry Science, 2007, 48 (03), pp.370-380. 10.1080/00071660701341963 . hal-00545311

\section{HAL Id: hal-00545311 \\ https://hal.science/hal-00545311}

Submitted on 10 Dec 2010

HAL is a multi-disciplinary open access archive for the deposit and dissemination of scientific research documents, whether they are published or not. The documents may come from teaching and research institutions in France or abroad, or from public or private research centers.
L'archive ouverte pluridisciplinaire HAL, est destinée au dépôt et à la diffusion de documents scientifiques de niveau recherche, publiés ou non, émanant des établissements d'enseignement et de recherche français ou étrangers, des laboratoires publics ou privés.

\section{(ㅇ)(1) $\$$}

Distributed under a Creative Commons Attribution - NonCommercial - NoDerivatives 44.0 


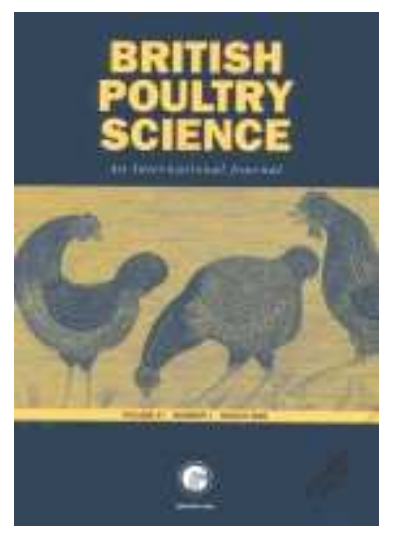

\section{Effects of two wheat cultivars on physico-chemical properties of wheat flours and digesta from two broiler chicken lines (D+ and D-) differing in digestion capacity.}

\begin{tabular}{|r|l|}
\hline Journal: & British Poultry Science \\
\hline Manuscript ID: & CBPS-2005-060.R2 \\
\hline Manuscript Type: & Original Manuscript \\
\hline Author: & 17-Jan-2007 \\
\hline Complete List of Authors: & $\begin{array}{l}\text { Péron, Alexandre; INRA, Unité de Recherches Avicoles } \\
\text { Svihus, Birger; Agricultural University of Norway, Animal and } \\
\text { Aquacultural Sciences } \\
\text { Gabriel, Irène; INRA, Unité de Recherches Avicoles } \\
\text { Bérot, Serge; INRA, Unité de Recherche sur les Protéines Végétales } \\
\text { et leurs Interactions } \\
\text { Tanguy, Daniel; INRA, UMR Physiologie de la Reproduction et } \\
\text { Comportement } \\
\text { Bouchet, Brigitte; INRA, Unité de Recherche sur les } \\
\text { Polysaccharides, leurs Organisations et leurs Interactions } \\
\text { Gomez, Joëlle; INRA, Unité de Recherches Avicoles } \\
\text { Carré, Bernard; INRA, Unité de Recherches Avicoles }\end{array}$ \\
\hline Keywords: & Digestion, Broilers, wheat, grain hardness, Genetics \\
\hline
\end{tabular}

\section{s ScholarONE" \\ Manuscript Central}




\section{CBPS-2006-060}

edited M G MacLeod, March 2007

3 Effects of two wheat cultivars on physico-chemical properties of wheat flours and

4 digesta from two broiler chicken lines $\left(\mathrm{D}^{+}\right.$and $\left.\mathrm{D}^{-}\right)$differing in digestion capacity

6 A. PÉRON, B. SVIHUS ${ }^{1}$, I. GABRIEL, S. BÉROT ${ }^{2}$, D. TANGUY ${ }^{3}$, B. BOUCHET ${ }^{4}$,

7 J. GOMEZ AND B. CARRÉ*

9 Unité de Recherches Avicoles, Institut National de la Recherche Agronomique (INRA),

1037380 Nouzilly, France, ${ }^{1}$ Department of Animal and Aquacultural Sciences,

11 Agricultural University of Norway, P.O. Box 5003, 1432 Ås, Norway, ${ }^{2}$ Unité de

12 Recherche sur les Protéines Végétales et leurs Interactions, INRA, 44316 Nantes,

13 France, ${ }^{3}$ UMR Physiologie de la Reproduction et du Comportement, INRA, 37380

14 Nouzilly, France and ${ }^{4}$ Unité de Recherche sur les Polysaccharides, leurs Organisations

15 et leurs Interactions, INRA, 44316 Nantes, France

16

17

\section{DIGESTION OF HARD WHEAT}

$21 *$ Corresponding author: carre@ tours.inra.fr

\section{Accepted for publication $16^{\text {th }}$ February 2007}


1 Abstract 1. The current experiment is the second part of a study about the effects of

2 wheat quality on digestibility of pelleted diets for broiler chickens. In the first part, it

3 was shown that a hard cultivar resulted in a negative effect on starch digestibility in two

4 divergent lines of chickens $\left(\mathrm{D}^{+}\right.$and $\left.\mathrm{D}^{-}\right)$selected for digestion capacity. The aim of this

5 second part was to investigate the reasons for this negative effect of a hard cultivar

6 (Baltimor) compared to a soft one (Scipion) in $\mathrm{D}^{+}$and $\mathrm{D}^{-}$lines.

7 2. Proventriculus pepsin activity and pancreas proteolytic and amylolytic activities were

8 estimated in 4 pools of birds: " $\mathrm{D}^{+}$line (Baltimor fed)", " $\mathrm{D}^{+}$line (Scipion fed)", " $\mathrm{D}^{-}$line

9 (Baltimor fed)" and "D- line (Scipion fed)". Results suggested greatest amount of pepsin

10 units per g BW for $\mathrm{D}^{+}$birds and lowest amount of pancreas proteolytic units per $\mathrm{g} \mathrm{BW}$

11 for $\mathrm{D}^{+}$birds fed Scipion wheat. Pancreas showed very similar $\alpha$-amylase activities

12 among treatments.

13 3. In vitro hydrolyses of wheat gluten proteins with proventriculus extracts from pools

14 of $\mathrm{D}^{+}$and $\mathrm{D}^{-}$birds did not show any differences between hard and soft cultivars,

15 whatever the origin of pools.

16 4. Pepsin hydrolysis of fine (300 to $425 \mu \mathrm{m})$ and coarse (1180 to $1600 \mu \mathrm{m})$ fractions

17 from wheat flours (Baltimor or Scipion) showed that the 30 min proteolysis rate was

18 highest for the fine fraction in both cultivars. No difference was observed with extended

19 hydrolysis time.

20 5. In vitro digestion simulation of whole wheat flours confirmed the results previously

21 obtained in vivo, with a negative effect of hard cultivar on starch digestion rate and no

22 effect on protein digestion.

23 6. Laser particle size analyses showed that ileum digesta from birds fed with hard wheat

24 cultivar showed highest proportion of coarse particles. 
1 7. Microscopic analyses of $\mathrm{D}^{+}$ileum digesta revealed that the concentration of

2 undigested starch granules in sub-aleurone area of wheat bran particles was the highest

3 with hard cultivar.

4 8. The results suggested that physical entrapment of starch granules in coarse particles

5 was a major explanation for decreased starch digestibility values in chickens fed hard

6 wheat diets.

\section{INTRODUCTION}

8 Hardness is a mechanical characteristic of wheat grain (Triticum aestivum) which is

9 thought to be due to interactions between starch granules and their surrounding protein

10 matrix (Barlow et al., 1973; Simmonds et al., 1973). Puroindolines a and b are major

11 proteins involved in this interaction (Giroux and Morris, 1998). High hardness value

12 results in less friable wheat endosperm and increased particle size after grain milling

13 (Abécassis et al., 1997). Recent studies have demonstrated the negative effect of hard

14 wheat cultivar on starch digestibility in pelleted diets for broiler chickens (Carré et al.,

15 2002, 2005; Péron et al., 2006). Some hypotheses have been proposed to explain this

16 negative effect, most of them involving an accessibility problem. Hard cultivar, high

17 particle size after grinding (Abécassis et al., 1997; Carré et al., 2002; Péron et al., 2006)

18 and/or strong starch-protein interactions (Barlow et al., 1973; Kim et al., 2004) could

19 decrease physical access to starch granules and limit enzymatic digestion. As previously

20 shown by Péron et al. (2005), fine grinding of a hard wheat cultivar before pelleting

21 resulted in starch digestibility and $\mathrm{AME}_{\mathrm{N}}$ improvements, indicating that particle size

22 could be an important factor affecting starch digestion of hard wheat. Concerning other

23 factors, it could also be supposed that protein matrix from hard cultivar is less

24 susceptible to proteases than protein matrix from soft cultivar. 
This work is the second part of an experiment (Péron et al., 2006) studying the

2 effect of wheat quality on digestibility values in two lines $\left(\mathrm{D}^{+}\right.$and $\left.\mathrm{D}^{-}\right)$of broiler

3 chickens selected for divergent digestion capacity (Mignon-Grasteau et al., 2004). The

4 first part of this experiment (Péron et al., 2006) confirmed that strong wheat hardness

5 was negative for starch digestibility in broiler chickens: soft (Scipion cultivar) instead

6 of hard (Baltimor cultivar) wheat resulted in an improvement of about $6 \%$ in both $\mathrm{D}^{+}$

7 and $\mathrm{D}^{-}$lines. The aim of the current paper was to investigate the causes for decreased

8 starch digestibility with hard wheat. Laser particle size and microscopic analyses in

9 ileum contents were used in order to observe possible differences in starch accessibility

10 between hard and soft wheat. In vitro hydrolyses and digestion simulation processes

11 were used to investigate hydrolysis susceptibility of hard and soft wheat gluten proteins

12 and wheat flours. In order to test possible interactions with genetical origin of birds,

13 digesta and enzyme extracts were taken from $\mathrm{D}^{+}$and $\mathrm{D}^{-}$chickens.

MATERIALS AND METHODS

\section{Animals, wheat cultivars and experimental diets}

16 Chickens, housing conditions, composition of the experimental diets, pelleting

17 parameters, particle size in diets, and in vivo digestibility measurements were described

18 in the first part of the study (Péron et al., 2006). Briefly, the experiment was performed

19 according to a $2 \times 2$ factorial design testing two chicken genetic lines ( $\mathrm{D}^{+}$and $\left.\mathrm{D}^{-}\right)$and

20 two wheat cultivars (Baltimor and Scipion). These cultivars were chosen because of

21 their great difference in hardness value (Table 1). Wheat samples were obtained from

22 plant breeders and were stored at ambient temperature before use in diets and in vitro

23 studies. Chemical and physical compositions of wheat samples are given in Table 1.

24 Before inclusion in diets, both wheat samples were ground using a hammer mill fitted

25 with a $6 \mathrm{~mm}$ screen. Particle size distribution of wheat flours is shown in Table 2. All 
1 diets were pelleted. From 7 to $26 \mathrm{~d}$ of age, birds were fed with diets containing $546 \mathrm{~g} / \mathrm{kg}$

2 wheat (Baltimor or Scipion), $353 \mathrm{~g} / \mathrm{kg}$ soybean meal and $55 \mathrm{~g} / \mathrm{kg}$ rapeseed oil (Péron et

$3 a l ., 2006)$. Digestibility measurements were performed from 20 to $23 \mathrm{~d}$. At $26 \mathrm{~d}$, two

4 new pelleted diets were offered to birds. They were just given for $1 \mathrm{~d}$ before killing

5 chickens and sampling their digestive organs and ileum contents. These new diets

6 contained the same wheat samples as previous diets, and differed from previous ones by

7 the high wheat inclusion rate $(942 \mathrm{~g} / \mathrm{kg})$. Other ingredients of these diets were rapeseed

8 oil $(20 \mathrm{~g} / \mathrm{kg})$ and a mixture $(38 \mathrm{~g} / \mathrm{kg})$ of lysine, methionine, minerals and vitamins (Péron

9 et al., 2006). Laser particle size distributions of the wheat $(942 \mathrm{~g} / \mathrm{kg})$ pelleted diets are

10 shown in Figure 2. Tables 1, 2; Figures 1, 2 near here

\section{Digestive organ and ileum content sampling}

12 Sampling procedure for digestive organs and their contents was described in Péron et al.

13 (2006). Briefly, at $27 \mathrm{~d}, 12$ birds per treatment were weighed and killed by intracardiac

14 injection of $1 \mathrm{ml}$ of sodium pentobarbital (Sanofi, Marne la Coquette, France) for

15 collection of digestive organs and ileum contents. Proventriculus and pancreas were

16 quickly frozen in liquid nitrogen, stored at $-70^{\circ} \mathrm{C}$, ground by ball-milling in liquid

17 nitrogen and stored again at $-70^{\circ} \mathrm{C}$. Total ileum content was homogenised and divided

18 into two fractions F1 and F2: fraction F1 was frozen in liquid nitrogen and stored at -

$1970^{\circ} \mathrm{C}$ for further laser particle size analyses, and fraction $\mathrm{F} 2$ was frozen with isopentane

20 (cooled with liquid nitrogen) and stored at $-70^{\circ} \mathrm{C}$ for further microscopic analyses. For

21 enzymatic studies (in vitro hydrolyses and digestion simulation), one pool of 6

22 proventriculi and one pool of 4 pancreases were carried out for each treatment. Pools

23 were constituted by mixing equal quantities of tissue powder from each bird. Pool

24 origins were designated as: " $\mathrm{D}^{+}$line (Baltimor fed)", " $\mathrm{D}^{+}$line (Scipion fed)", " $\mathrm{D}^{-}$line 25 (Baltimor fed)" and "D line (Scipion fed)". 


\section{Analytical methods}

2 In order to prepare in vitro hydrolyses and digestion simulation, some activities of

3 digestive enzymes of $\mathrm{D}^{+}$and $\mathrm{D}^{-}$lines were investigated. Pepsin activity (EC 3.4.23.1) in

4 proventriculus tissue was assayed at different $\mathrm{pH}$ with haemoglobin as a substrate. Two

5 analytical replicates were performed for each proventriculus pool. Anson's method

6 (1938) modified by Crévieu-Gabriel et al. (1999) was used with some modifications as

7 follows: $100 \mathrm{mg}$ tissue powder was homogenised in $2 \mathrm{ml}$ of $0.01 \mathrm{M}$ phosphate buffer

$8 \mathrm{pH}=7.4$, then centrifuged at $10000 \mathrm{~g}\left(4^{\circ} \mathrm{C}, 15 \mathrm{~min}\right)$. Supernatants $(50 \mu \mathrm{l})$ were diluted

9 with $950 \mu \mathrm{l}$ of $0.01 \mathrm{M}$ phosphate buffer $\mathrm{pH}=7.4$. Then, $500 \mu \mathrm{l}$ of diluted extract were

10 activated with $100 \mu \mathrm{HCl} 300 \mathrm{mM}$ for 15 minutes and pepsin activity was measured by

11 adding $200 \mu \mathrm{l}$ of the activated extract in $1.35 \mathrm{ml}$ of a haemoglobin solution $(20 \mathrm{~g} / \mathrm{l})$.

12 Pepsin activity of proventriculus was expressed as units/mg tissue. According to

13 Crévieu-Gabriel et al. (1999), one pepsin unit (U) was defined as the amount of enzyme

14 that increased optical density $(280 \eta \mathrm{m})$ by 0.001 per min under the assay conditions.

15 Proteolytic activity of pancreas was measured (with 4 replicates per pancreas pool) at

16 different $\mathrm{pH}$ values using a casein substrate, as described by Susbilla et al. (2003).

17 Pancreas proteolytic activity was expressed as units/g tissue, with 1 proteolytic unit (U)

18 being equivalent to $1 \mu$ mole tyrosine released per min under the assay conditions.

19 Amylolytic activity of pancreas was estimated (with 2 replicates per pancreas pool)

20 using $50 \mathrm{mg}$ purified maize starch (Roquette, France) suspended in $1 \mathrm{ml}$ of sodium-

21 phosphate buffer $0.05 \mathrm{M}(\mathrm{pH}=6.75)$ and placed in a thermostatically controlled water

22 bath $\left(40^{\circ} \mathrm{C}\right)$. Pancreatic extract $(490 \mu \mathrm{l}$ from $150 \mathrm{mg}$ homogenised tissue in $2.5 \mathrm{ml}$

23 Ringer solution $\mathrm{pH}=7.4$ ) was added to the suspension. At various times of the

24 hydrolysis process ( $\mathrm{t}=30 \mathrm{~min}, 1 \mathrm{~h}, 2 \mathrm{~h}, 3 \mathrm{~h}$ or $4 \mathrm{~h}$ ), an aliquot was kept and centrifuged 
1 at 10000 g. Released dextrins in the supernatant were determined using

2 amyloglucosidase treatment followed by glucose determination (Carré et al., 2002). In vitro protein hydrolyses with proventriculus extracts were also performed on

4 wheat gluten suspensions with 3 replicates per pool extract. Gluten was obtained by

5 lixiviation (Bérot and Davin, 1996) from the wheat samples (Baltimor and Scipion

6 cultivars) given to birds. Hydrolyses were performed in Erlenmeyer flasks closed with

7 synthetic rubber bungs, placed in a thermostatically controlled water bath $\left(40^{\circ} \mathrm{C}\right)$, under

8 magnetic stirring (180 rpm). To each Erlenmeyer, $10 \mathrm{ml}$ of $\mathrm{HCl}(\mathrm{pH}=3.0)$ were added.

9 When the correct temperature was reached, $50 \mathrm{mg}$ of wheat gluten were also added.

10 They were suspended for $10 \mathrm{~min}$ and the proventriculus extracts (414 pepsin U 11 activated with $100 \mu \mathrm{HCl} 300 \mathrm{mM}$ during $15 \mathrm{~min}$ ), were added to the suspension.

12 Hydrolyses were allowed to proceed for $10 \mathrm{~min}$ at $40^{\circ} \mathrm{C}$. Reactions were stopped by 13 adding TCA for a final concentration of $100 \mathrm{~g} / \mathrm{l}$. Blanks were made by adding TCA

14 before the proventriculus extract. Then, suspensions were left at $4^{\circ} \mathrm{C}$ for $30 \mathrm{~min}$. TCA 15 precipitates were discarded after centrifugation at $10000 \mathrm{~g}$ for $10 \mathrm{~min}$ at $4^{\circ} \mathrm{C}$. TCA16 soluble products were measured by Landry and Delhaye's method (1996) modified by

17 Crévieu-Gabriel et al. (1999).

18 Kinetics of protein hydrolysis by proventriculus extracts were performed on two

19 fractions (fine or coarse particles) of Baltimor and Scipion wheat flours, as described 20 above for gluten, with various times of hydrolysis from $30 \mathrm{~min}$ to $4 \mathrm{~h}$, using the 21 proventriculus extract (414 pepsin $\mathrm{U}$ activated with $100 \mu \mathrm{HCl} 300 \mathrm{mM}$ for $15 \mathrm{~min}$ ) 22 from the " $\mathrm{D}^{+}$line (Baltimor fed)" pool and flour samples equivalent to $50 \mathrm{mg}$ protein. 23 Coarse and fine flour fractions were obtained by dry sieving of the whole flour included 24 in diets for chicken experiment (particle size distribution is shown in Table 2). Two 25 replicates per pool and per hydrolysis time were carried out. 
With whole wheat flours from hard and soft cultivars (particle size distribution is

2 shown in Table 2), in vitro digestion simulation was also performed. Whole wheat

3 flours were the same as those included in diets. The physiological parameters of the

4 intestinal tract used for this study, such as temperature, $\mathrm{pH}$, or digesta retention time,

5 were simulated by an in vitro method described by Tervilä-Wilo et al. (1996), with

6 some modifications. $200 \mathrm{mg}$ of whole wheat flour were hydrolysed using enzymatic

7 extracts from the " $\mathrm{D}^{+}$line (Baltimor fed)" pool. Proventriculus and pancreas enzymatic

8 activities added were respectively 1000 pepsin $\mathrm{U}$ (activated with $100 \mu \mathrm{HCl} 300 \mathrm{mM}$

9 during $15 \mathrm{~min}$ ) and 2.3 proteolytic $\mathrm{U}$ (activated with $6.25 \mu \mathrm{g}$ enterokinase in $25 \mu \mathrm{l}$ Tris-

$10 \mathrm{HCl}$ buffer $\mathrm{pH}=7.4$ for $2 \mathrm{~h}$ ). In order to obtain noticeable starch hydrolysis, the

11 pancreatic step was longer (6h 00) than in the method of Terwilä-Wilo et al. (1996) (1h

12 00). After centrifugation, supernatants were assayed for protein and starch contents,

13 according to Lowry et al. (1951) and Carré et al. (2002), respectively.

14 Particle size distributions in ileum contents and in the wheat $(942 \mathrm{~g} / \mathrm{kg}$ ) pelleted

15 diets (Baltimor and Scipion cultivars) were determined (12 birds replicates for $\mathrm{D}^{+}$

16 Baltimor and $\mathrm{D}^{-}$Scipion, and 11 for $\mathrm{D}^{+}$Scipion and $\mathrm{D}^{-}$Baltimor) using a Malvern

17 Mastersizer S instrument (Malvern Instruments Ltd., Worcestershire, UK), as described

18 by Hetland et al. (2002). Particle diameters were detected in the range from 0.02 to

$192000 \mu \mathrm{m}$. Results were analysed using the Malvern 2000 Software (version 5.22).

20 Fluorescence microscopy was performed on an ileum sample from a $\mathrm{D}^{+}$bird fed

21 on Baltimor, as follows: sections $(16 \mu \mathrm{m})$ obtained from a portion frozen at $-25^{\circ} \mathrm{C}$ were

22 allowed to dry for one week. They were then stained for $5 \mathrm{~min}$ with $100 \mathrm{mg} / \mathrm{l}$

23 Calcofluor (White M2R; Sigma) and quickly rinsed with distilled water. The

24 fluorescence section was examined with a Zeiss Axioplan 2 microscope, fitted with an

25 appropriate filter set (Zeiss, $\mathrm{n}^{\circ} 18$ ) and phase interference (H/DIC II). Bright-field 
1 microscopy was preferred to fluorescence because the staining process to be used with

2 the latter observation technique resulted in starch granule losses. These losses were

3 observed by comparing successive sections treated either with the bright-field technique

4 or with the fluorescence one. Bright-field microscopy analyses were made on ileum

5 contents of $\mathrm{D}^{+}$birds only ( $\mathrm{n}=11$ birds per diet). For bright-field microscopy, the sections

$6(16 \mu \mathrm{m})$ were not stained and were observed with no preliminary treatment. Bright-field

7 sections were examined with a Zeiss Axioplan 2 microscope, fitted with phase

8 interference (H/DIC II). Photomicrographs were obtained using a Kappa camera

9 DX30C and analysed with Visilog Software (version 6.3). The software was

10 programmed in order to measure the length $(\mu \mathrm{m})$ of particles. It was also able to

11 measure the concentration of starch granules in a defined area as the mean optical

12 density (OD) of this area. Observations were made of the subaleurone area of bran

13 particles. The subaleurone area was defined as described in Figure 3, with $75 \mu \mathrm{m}$ width

14 for the considered area. An enlarged view of the subaleurone area is also shown in

15 Figure 4. About 10 particles per animal were observed.

\section{Statistical analysis}

17 ANOVA analyses with Statview Software (SAS Institute) were used to test the effects

18 of "line" and "cultivar" for in vitro hydrolyses, digestion simulation procedure and laser

19 particle size analyses. For image analysis of ileum sections, GLM analyses with SAS

20 Software were used to test the effects of "cultivar", and "individual chicken nested in a

21 cultivar", on the length of bran particles and on the estimated starch concentration in the

22 subaleurone area of bran particles.

RESULTS

\section{Proventriculus and pancreas enzymatic activities}


1 Pepsin activities of proventriculus on haemoglobin at various $\mathrm{pH}$ are shown in Table 3.

2 Optimum $\mathrm{pH}$ level of the activity was found to be around 3.0 for each treatment. Pepsin

3 activities expressed as U/g BW (Table 4) suggested higher activity in $\mathrm{D}^{+}$than in $\mathrm{D}^{-}$

4 birds. Proteolytic activities of pancreas on casein at various $\mathrm{pH}$ are shown in Table 3.

5 Activity increased from $\mathrm{pH}=6.15$ to 7.50 . Pancreatic proteolytic activities expressed as

6 U/g BW (Table 4) suggested lowest activity for $\mathrm{D}^{+}$birds fed the Scipion wheat diet.

7 Kinetic of starch hydrolysis with pancreatic extracts suggested very similar $\alpha$-amylase

8 concentration in pancreas among treatments (Table 3 ).

Tables 3, 4 near here

9 Gluten hydrolyses with proventriculus extracts

10 Hydrolyses of gluten from Baltimor or Scipion wheats with proventriculus extracts are

11 shown in Table 5. There were no significant differences between hard and soft wheat

12 cultivars, whatever the origin of proventriculus extract.

13 Hydrolyses of fine and coarse wheat fractions with proventriculus extracts

14 Results for the kinetic hydrolyses of fine (300 to $425 \mu \mathrm{m}$ ) or coarse (1180 to $1600 \mu \mathrm{m})$

15 fractions from wheats (Baltimor or Scipion) with proventriculus extract from the " $\mathrm{D}^{+}$

16 line (Baltimor fed)" pool are shown in Figure 1. There were no significant effects except

17 at $\mathrm{t}=30 \mathrm{~min}$. At this time, protein hydrolysis was significantly higher $(P=0.016)$ in fine

18 than in coarse particles.

Figure 1 near here

19 In vitro digestion simulation

20 Results of in vitro digestion simulation on whole wheat flours (Baltimor versus Scipion)

21 are shown in Table 6. Starch hydrolysis values were low (around 0.30). Hard cultivar

22 instead of soft one resulted in a negative effect $(P<0.001)$ on starch digestibility. There

23 were no differences in protein hydrolysis between cultivars. Tables 5, 6 near here

24 Laser particle size analysis of ileum contents and wheat $(942 \mathrm{~g} / \mathrm{kg})$ pelleted diets 
1 Laser particle size distributions of the wheat $(942 \mathrm{~g} / \mathrm{kg}$ ) pelleted diets (Baltimor or

2 Scipion cultivars) and ileum contents of birds fed these diets are shown in Figure 2.

3 Statistical analyses for particle size analysis of chicken ileum contents are shown in

4 Table 7. It was observed that the pattern of the distributions was not very different

5 between diets and related ileum contents. However, distributions in ileum contents of

6 birds were shifted towards lower sizes, compared with those of the wheat $(942 \mathrm{~g} / \mathrm{kg})$

7 pelleted diets (Figure 2). Moreover, the soft cultivar resulted in an increased proportion

8 of small particles in ileum compared to the diet, while the reverse was observed with the

9 hard cultivar (Figure 2). Particle size histograms exhibited one mode (main mode) or

10 two mode (bimodal) response types. For the main mode response type, ileum particles

11 of $\mathrm{D}^{+}$chickens tended $(P=0.062)$ to show smaller single peak position than those of $\mathrm{D}^{-}$

12 chickens. Proportion of ileum particles at this single peak position did not differ

13 between treatments. With bimodal response type, ileum particles from soft wheat

14 showed lower peak 1 position than hard one $(18.8 \mu \mathrm{m}$ versus $20.7 \mu \mathrm{m})(P<0.001)$, and

15 the proportion of ileum particles at this peak 1 position was higher $(P=0.003)$ for

16 Scipion than for Baltimor. Peak 2 position did not differ between treatments. $\begin{gathered}\text { Figure 2, Table } 7 \\ \text { near here }\end{gathered}$

17 In order to study all animal responses together, two peak positions $(\mu \mathrm{m})$ were

18 investigated: a small one at $17.4 \mu \mathrm{m}$ (mean peak 1 position of mean particle size

19 histograms shown in Figure 2) and a coarse one at $478.6 \mu \mathrm{m}$ (mean peak 2 position of

20 mean particle size histograms shown in Figure 2; Table 7). At $17.4 \mu \mathrm{m}$, proportions of

21 particles were higher for Scipion than for Baltimor $(P=0.005$; Table 7$)$, and at 478.6

$22 \mu \mathrm{m}$, particle proportions were lowest for Scipion $(P=0.045$; Table 7). No significant

23 effect of chicken line was observed on particle proportion at these two positions.

\section{Microscopy}


1 Results for microscopic analyses are shown in Table 8 and Figures 3, 4 and 5. It was

2 decided to analyze only $\mathrm{D}^{+}$line ileum digesta because these birds have less variable

3 responses, which could improve detection of differences. With the bright-field

4 observation technic, the visible structures were essentially starch granules and cell walls

5 from aleurone and/or bran layers (Figure 3). Few diffuse structures, maybe proteins,

6 were also visible. All these structures appeared as grey, with different intensity

7 according to their concentration. Concerning endosperm cell walls, they were only

8 visible using fluorescence (Figure 5). Image analyses revealed that the concentration of

9 starch granules remaining in the sub-aleurone area of ileum bran particles was higher

10 for hard than for soft wheat $(P<0.001$; Table 8$)$.

Figures 3,4,5, Table 8 near here

\section{DISCUSSION}

12 Particle size distribution was measured in the current experiment using a high

13 performance laser apparatus, which resulted in high precision in the data and a very

14 large range in particle size recording $(0.02 \mu \mathrm{m}$ to $2000 \mu \mathrm{m})$. The small peak (peak 1$)$

15 appearing in the particle size distributions of ileum digesta probably corresponded to

16 starch granules, especially because the variability of its position was very low in

17 bimodal responses. The effect of hardness on the position of this small peak probably

18 came directly from the diet that exhibited also the same effect. This probably reflected a

19 difference in the size of starch granules between Scipion and Baltimor cultivars. This

20 would be in agreement with previous observations (Bechtel et al., 1993) showing

21 difference in starch granule size between cultivars. The pattern of particle size

22 distributions in ileum digesta of chickens was shifted towards the left (decreased

23 particle size) compared to those of diets. This probably came from the erosive and

24 grinding activity of the digestive tract. The variability in particle size distribution in

25 ileum digesta was high, especially in $\mathrm{D}^{-}$birds fed on the Scipion diet. It remains to be 
1 known whether this variability not only reflected variability between birds, but also

2 variability in the digestion process of a bird.

3 The current experiment gave the opportunity to test the differences between $\mathrm{D}^{+}$

4 and $\mathrm{D}^{-}$lines in terms of digestive enzymatic activities. The high potential of $\mathrm{D}^{+}$birds for

5 pepsin production may be one of the reasons explaining their high digestion capacity.

6 Potential of $\mathrm{D}^{+}$birds fed Scipion diet for the production of pancreatic proteolytic

7 enzymes seemed rather low. This group also exhibited the highest protein digestibility

8 (Péron et al., 2006). Thus, it is probable that pancreatic enzyme syntheses were not

9 limiting and changed in order to counterbalance digestion levels resulting from some

10 unknown limiting factors. In general, it was observed that organ weight variation was

11 the main factor at the origin of the variation in the potential for enzyme production

12 expressed per gram of body weight.

13 In relation to the wheat quality effect, Péron et al. (2006) observed decreased

14 starch digestibility with hard wheat cultivar compared to soft wheat cultivar in both

15 chicken lines $\mathrm{D}^{+}$and $\mathrm{D}^{-}$. This could come from various factors in hard wheat such as

16 starch accessibility problems due to great amount of coarse particles, strong starch-

17 protein interaction, or resistance of matrix proteins.

18 In vitro digestion simulation of whole wheat flours showed a negative effect of

19 hard cultivar on starch hydrolysis, as previously shown in vivo (Péron et al., 2006).

20 However, in vitro starch hydrolysis values were low (around 0.30). This may have been

21 due to an insufficient addition of pancreatic enzymes compared with the amount

22 secreted in vivo by chickens. It could also be supposed that a part of the observed

23 difference in in vitro starch hydrolysis could be due to different concentrations of

24 endogenous $\alpha$-amylase or $\alpha$-amylase inhibitors between cultivars. These values were not

25 measured in this experiment. 
Observation of particle size distribution in ileum digesta allowed us to estimate

2 the location of undigested starch granules among particles of ileum digesta. High

3 amount of undigested free starch granules should result in high proportion of small

4 particles $(<30 \mu \mathrm{m})$ in ileum digesta. This was not observed in ileum digesta of birds fed

5 hard wheat, despite low starch digestion with this kind of wheat. Thus, for hard wheat,

6 the major part of undigested starch granules was probably located in coarse particles,

7 which suggests an accessibility problem in coarse particles for the starch digestion of

8 hard wheat. The reverse was observed with soft wheat: despite high starch digestion, a

9 large amount of small particles was found. Thus, the limiting factor for starch digestion

10 probably did not concern free starch granules digestion. Moreover, in the present

11 experiment, in vitro proteolysis of fine and coarse particles from wheat flours with

12 pepsin extract gave higher hydrolysis values at 30 minutes for the finest particles in

13 both cultivars. This observation reinforce the hypothesis of an access problem in coarse

14 particles of ground wheat. Rather similar observations were made, in vitro, by Weiguo

15 et al. (2003) with ground maize or ground wheat bran. However, after 4 h of hydrolysis,

16 there was no significant difference in proteolysis value between treatments, indicating

17 that the access problem acted essentially by creating a lag time in the digestion process.

18 It can also be noted that protein hydrolysis values for in vitro hydrolysis of fine and

19 coarse flour fractions were low (about 0.20) compared with those obtained with in vitro

20 digestion simulation of whole flours (about 0.80). This may have been due to the fact

21 that, for the simulation procedure, added pepsin activity was higher and flour amount

22 was lower, resulting in a better enzyme/substrate ratio. Higher protein hydrolysis values

23 in the simulation digestion procedure may also have been related to the presence of

24 pancreatic proteases in addition to pepsin 
It has previously been shown that, in the human small intestine, undigested

2 starch granules of barley were mainly located close to the aleurone and bran layers

3 (Livesey et al., 1995). In the current experiment, a large amount of undigested starch

4 granules was also observed in the endosperm subaleurone area of bran particles found in

5 the ileum. Microscopic analyses of these particles showed that the amount of starch in

6 the endosperm subaleurone area was higher for the hard than for the soft wheat ileum

7 samples. This suggests that the problem of access with hard wheat mainly concerned the

8 endosperm subaleurone area. Subaleurone cells from hard wheat may be more resistant

9 and then, after grinding, starch granules may be more protected from enzyme

10 hydrolysis. Such a difference in resistance might be related to the difference in 11 composition of subaleurone cell walls between hard and soft wheats (Barron et al., 12 2005).

13 A previous study showed that adding protease (such as pepsin) could increase in

14 vitro starch digestibility of cereals (Aura et al., 1999), indicating that the resistance of

15 the protein matrix surrounding starch granules may affect starch digestion. Gluten is the

16 major component of the protein matrix. Gluten hydrolyses with proventriculus extracts

17 showed that there were no differences between hard and soft cultivar origins of gluten,

18 which suggests that gluten was not involved. It might be supposed that 10 minutes of

19 hydrolysis was too short to result in observation of notable differences. However, with

20 the hydrolysis of fine and coarse particles from Baltimor and Scipion wheat flours, or

21 with the in vitro digestion simulation of whole flours, protein hydrolysis was longer (4 $\mathrm{h}$

22 or $6.75 \mathrm{~h}$, respectively) and no significant differences were observed between hard and

23 soft wheat flours. Thus, differences in starch digestibility probably did not result from

24 differences in protein susceptibility to enzyme hydrolysis. 
1 In conclusion, the current experiment seemed to confirm in vitro the negative effect of a

2 hard cultivar on the in vivo digestion of wheat starch observed by Péron et al. (2006).

3 However, other factors such as endogenous $\alpha$-amylase or $\alpha$-amylase inhibitors in grain

4 may have been involved in this observation. The use of isogenic lines of wheat might be

5 an interesting solution to understand more precisely the role of hardness independently

6 of the other factors. Concerning explanations for the negative effect of hard wheat

7 cultivar on starch digestibility, most observations were in favour of the hypothesis of an

8 access problem in coarse particles of hard wheat, as shown by in vitro hydrolyses of

9 wheat flours, and examinations of chicken ileum digesta using laser particle size

10 determinations or light microscope analyses.

\section{AKNOWLEDGMENTS}

12 The authors are grateful to $\mathrm{INZO}^{\circ}$ (Château-Thierry, France) for financial support. They

13 also thank Ms M. Leconte (INRA, Nouzilly, France) for advice in the in vitro digestion

14 procedures, Mr F. Sunby (Agricultural University of Norway) for laser particle size

15 measurements, Mr K. Gérard (INRA, Nouzilly, France) for helpful assistance in the

16 management of birds, Ms I. Grasseau and Mr J.P. Brillard (INRA, Nouzilly, France) for

17 advice in microscopy, and $\mathrm{Mr} \mathrm{C}$. Blassel (INRA, Nantes, France) for preparation of 18 gluten from wheat flours.

\section{REFERENCES}

20 ABÉcAssis, J., MABIlle, F., HADDAD, Y., AUTRAN, J.-C. \& BENET, J.-C. 21 (1997) La dureté des blés : état des connaissances actuelles. Industrie des 22 céréales, 101: 11-18.

23 ANSON, M.L. (1938) The estimation of pepsin, trypsin, papain, and cathepsin with 24 haemoglobin. Journal of General Physiology, 22: 79-89. 
ASAE (1983) Method of determining and expressing fineness of feed materials by sieving. ASAE standard S319, in: Agricultural Engineers Yearbook of Standards, p325 (American Society of Agricultural Engineers).

AURA, A.M., HÄRKÖNEN, H., FABRITIUS, M. \& POUTANEN, K. (1999) Development of an in vitro enzymatic digestion method for removal of starch and protein and assessment of its performance using rye and wheat breads. Journal of Cereal Science, 29: 139-152.

BARLOW, K.K., BUTTROSE, M.S., SIMMONDS, D.H. \& VESK, M. (1973) The nature of the starch-protein interface in wheat endosperm. Cereal Chemistry, 50: 443-454.

BARRON, C., PARKER, M.L., MILLS, E.N.C. \& ROUAU, X. (2005) FTIR imaging of wheat endosperm cell walls in situ reveals compositional and architectural heterogeneity related to grain hardness. Planta, 220: 667-677.

BECHTEL, D.B., ZAYAS, I., DEMPSTER, R. \& WILSON, J.D. (1993) Sizedistribution of starch granules isolated from hard red winter and soft red winter wheats. Cereal Chemistry, 70: 238-240.

BÉROT, S. \& DAVIN, A. (1996) Technologie d'extraction et de purification des matières protéiques végétales, in: Lavoisier Tech. Doc. (Eds) Les protéines végétales, pp 279-363.

CARRÉ, B. \& BRILLOUET, J.M. (1989) Determination of water-insoluble cell walls in feeds : interlaboratory study. Journal of the Association of Official Analytical Chemists, 72: 463-467.

CARRÉ, B., BEAUFILS, E. \& MELCION, J.P. (1991) Evaluation of protein and starch digestibilities and energy value of pelleted or unpelleted pea seeds from winter or spring cultivars in adult and young chickens. Journal of Agricultural and 
Food Chemistry, 39: 468-472.

2 CARRÉ, B., GOMEZ, J., MELCION, J.P. \& GIBOULOT, B. (1994) La viscosité des aliments destinés à l'aviculture. Utilisation pour prédire la consommation et l'excrétion d'eau. Productions Animales, 7: 369-379.

CARRÉ, B., IDI, A., MAISONNIER, S., MELCION, J.P., OURY, F.X., GOMEZ, J. \& PLUCHARD, P. (2002) Relationships between digestibilities of food components and characteristics of wheats (Triticum aestivum) introduced as the only cereal source in a broiler chicken diet. British Poultry Science, 43: 404415.

CARRÉ, B., MULEY, N., GOMEZ, J., OURY, F.X., LAFFITTE, E., GUILLOU, D. \& SIGNORET, C. (2005) Soft wheat instead of hard wheat in pelleted diets results in high starch digestibility in broiler chickens. British Poultry Science, 46: 6674.

CRÉVIEU-GABRIEL, I., GOMEZ, J., CAFFIN, J.P. \& CARRÉ, B. (1999) Comparison of pig and chicken pepsins for protein hydrolysis. Reproduction Nutrition and Development, 39: 443-454.

GIROUX, M.J. \& MORRIS, C.F. (1998) Wheat grain hardness results from highly conserved mutations in the friabilin components puroindoline $a$ and $b$. Proceedings of the National Academy of Science of the USA, 95: 6262-6266.

HETLAND, H., SVIHUS, B. \& OLAISEN, V. (2002) Effect of feeding whole cereals on performance, starch digestibility and duodenal particle size distribution in broiler chickens. British Poultry Science, 43: 416-423.

KIM, W., CHOI, S.G., KERR, W.L., JOHNSON, J.W. \& GAINES, C.S. (2004) Effect of temperature on particle size distribution in hard and soft wheat flour. Journal of Cereal Science, 40: 9-16. 
1 LANDRY, J. \& DELHAYE, S. (1996) A simple and rapid procedure for hydrolysing minute amounts of proteins with alkali. Analytical Biochemistry, 243: 191-194.

LIVESEY, G., WILKINSON, J.A., ROE, M., FAULKS, R., CLARK, S., BROWN, J.C., KENNEDY, H. \& ELIA, M. (1995) Influence of the physical form of barley grain on the digestion of its starch in the human small intestine and

7 LOWRY, O.H., ROSEBROUGH, N.J., FARR, A.L. \& RANDALL, R.J. (1951) Protein measurement with the Folin phenol reagent. Journal of Biological Chemistry, 193: $265-275$.

MiGNON-GRASTEAU, S., MULEY, N., BASTIANELLI, D., GOMEZ, J., PÉRON, A., SELliER, N., MILLET, N., BESNARD, J., HALlOUIS, J.M. \& CARRÉ, B. (2004) Heritability of digestibilities and divergent selection for digestion ability in growing chicks fed on a wheat diet. Poultry Science, 83: 860-866.

PÉRON, A., BASTIANElli, D., OURY, F.X., GOMEZ, J. \& CARRÉ, B. (2005) Effects of food deprivation and particle size of ground wheat on digestibility of food components in broilers fed a pelleted diet. British Poultry Science, 46: 223230.

PÉRON, A., GOMEZ, J., MIGNON-GRASTEAU, S., SELlIER, N., DEROUET, M., JUIN, H., CARRÉ, B. (2006) Effects of wheat quality on digestion differ

22 SIMMONDS, D.H., BARLOW, K.K. \& WRIGLEY, C.W. (1973) The biochemical 23 basis of grain hardness in wheat. Cereal Chemistry, 50: 553-562. 
1 SUSBILLA, J.P., TARVID, I., GOW, C.B. \& FRANKEL, T.L. (2003) Quantitative

2 feed restriction or meal-feeding of broiler chicks alter functional development of

3 enzymes for protein digestion. British Poultry Science, 44: 698-709.

4 TERVILÄ-WILO, A., PARKKONEN, T., MORGAN, A., HOPEAKOVSKI-

5 NURMINEN, M., POUTANEN, K., HEIKKINEN, P. \& AUTIO, K. (1996) In

6 vitro digestion of wheat microstructure with xylanase and cellulase from

7 trichoderma reesei. Journal of Cereal Science, 24: 215-225.

8 WEIGUO, W., PING, L., JUNQING, W., YIQIANG, X., HUANLONG, L. (2003)

9 Effect of particle sizes on in vitro protein digestibility and energy consumption

10 of seven feed ingredients. Chinese Journal of Animal Science, 39: 18-20.

11 
Table 1. Chemical and physical composition of wheat samples from Baltimor and Scipion cultivars

\begin{tabular}{|c|c|c|}
\hline & Baltimor & Scipion \\
\hline Crude protein $(\mathrm{g} / \mathrm{kg})$ & 101.9 & 111.5 \\
\hline $\operatorname{Starch}^{1}(\mathrm{~g} / \mathrm{kg})$ & 612.7 & 590.4 \\
\hline Water-insoluble cell walls ${ }^{2}(\mathrm{~g} / \mathrm{kg})$ & 103.0 & 93.1 \\
\hline Real Applied Viscosity ${ }^{3}(\mathrm{~mL} / \mathrm{g})$ & 1.73 & 2.18 \\
\hline Potential Applied Viscosity ${ }^{3}(\mathrm{~mL} / \mathrm{g})$ & 2.91 & 3.15 \\
\hline NIR hardness value & 75 & 5 \\
\hline
\end{tabular}

1: Starch according to Carré et al. (1991).

2: Water-insoluble cell walls (WICW) according to Carré and Brillouet (1989).

${ }^{3}$ : Viscosity determinations according to Carré et al. (1994), using the ethanol pretreatment for the Potential Applied Viscosity value. 
Table 2. Particle size distribution (weight proportion $(\mathrm{g} / \mathrm{g}$ ) retained on sieves) of ground wheat (dry and wet sieving)

\begin{tabular}{|c|c|c|c|c|c|c|c|c|c|c|c|c|c|c|}
\hline $\begin{array}{c}\text { Sieve } \\
\text { openings }(\mu \mathrm{m})\end{array}$ & & $<75$ & 75 & 150 & 300 & 425 & 600 & 850 & 1180 & 1600 & 2000 & 2360 & $\begin{array}{l}\mathrm{GMD}^{1} \\
(\mu \mathrm{m})\end{array}$ & $\begin{array}{c}\text { Ratio }^{2} \\
\text { Coarse/Fine }\end{array}$ \\
\hline $\begin{array}{c}\text { Wheat } \\
\text { flour } \\
\text { (dry sieving) }\end{array}$ & $\begin{array}{l}\text { Baltimor } \\
\text { Scipion }\end{array}$ & $\begin{array}{l}0.002 \\
0.005\end{array}$ & $\begin{array}{l}0.038 \\
0.034\end{array}$ & $\begin{array}{l}0.038 \\
0.041\end{array}$ & $\begin{array}{l}0.048 \\
0.073\end{array}$ & $\begin{array}{l}0.052 \\
0.071\end{array}$ & $\begin{array}{l}0.089 \\
0.093\end{array}$ & $\begin{array}{l}0.103 \\
0.093\end{array}$ & $\begin{array}{l}0.244 \\
0.191\end{array}$ & $\begin{array}{l}0.247 \\
0.297\end{array}$ & $\begin{array}{l}0.084 \\
0.062\end{array}$ & $\begin{array}{l}0.054 \\
0.038\end{array}$ & $\begin{array}{l}908 \\
854\end{array}$ & $\begin{array}{l}1.10 \\
0.65\end{array}$ \\
\hline $\begin{array}{c}\text { Wheat } \\
\text { flour } \\
\text { (wet sieving) }\end{array}$ & $\begin{array}{l}\text { Baltimor } \\
\text { Scipion }\end{array}$ & $\begin{array}{l}0.232 \\
0.283\end{array}$ & $\begin{array}{l}0.025 \\
0.086\end{array}$ & $\begin{array}{l}0.017 \\
0.033\end{array}$ & $\begin{array}{l}0.016 \\
0.027\end{array}$ & $\begin{array}{l}0.028 \\
0.033\end{array}$ & $\begin{array}{l}0.091 \\
0.085\end{array}$ & $\begin{array}{l}0.110 \\
0.099\end{array}$ & $\begin{array}{l}0.158 \\
0.122\end{array}$ & $\begin{array}{l}0.158 \\
0.118\end{array}$ & $\begin{array}{l}0.165 \\
0.115\end{array}$ & & $\begin{array}{l}481 \\
320\end{array}$ & $\begin{array}{l}1.18 \\
0.58\end{array}$ \\
\hline
\end{tabular}

${ }^{1}$ Geometrical Mean Diameter. calculated according to ASAE method (1983).

${ }^{2}$ Ratio of coarse to small particles.

For dry sieving: $(2360+2000) /(<75+75+150+300)$

For wet sieving: $(2000+1600) /(<75+75+150)$. 
Table 3. Proteolytic enzyme activities in proventriculus ${ }^{1}$ and pancreas $^{2}$ (expressed as U/mg tissue or U/g tissue) at $27 \mathrm{~d}$, and kinetics of hydrolysis of pure maize starch with pancreatic extract ${ }^{3}$

\begin{tabular}{|c|c|c|c|c|}
\hline \multirow[t]{2}{*}{ 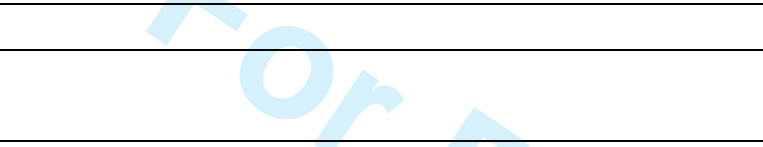 } & \multicolumn{4}{|c|}{ Origin of pools } \\
\hline & $\begin{array}{c}\mathrm{D}+\text { line } \\
\text { (Baltimor fed) }\end{array}$ & $\begin{array}{c}\text { D+ line } \\
\text { (Scipion fed) }\end{array}$ & $\begin{array}{c}\text { D- line } \\
\text { (Baltimor fed) }\end{array}$ & $\begin{array}{c}\text { D- line } \\
\text { (Scipion fed })\end{array}$ \\
\hline Proventriculus pepsic activity ${ }^{4}$ (U/mg tissue) at $\mathrm{pH}=1$ & 5.6 & 6.6 & 8.3 & 8.2 \\
\hline Proventriculus pepsic activity ${ }^{4}(\mathrm{U} / \mathrm{mg}$ tissue $)$ at $\mathrm{pH}=2$ & 14.5 & 15.0 & 16.8 & 17.9 \\
\hline Proventriculus pepsic activity ${ }^{4}(\mathrm{U} / \mathrm{mg}$ tissue $)$ at $\mathrm{pH}=3$ & 16.5 & 17.5 & 18.3 & 19.2 \\
\hline Proventriculus pepsic activity $^{4}$ (U/mg tissue) at $\mathrm{pH}=4$ & 14.7 & 14.9 & 14.8 & 15.4 \\
\hline Proventriculus pepsic activity ${ }^{4}(\mathrm{U} / \mathrm{mg}$ tissue $)$ at $\mathrm{pH}=5$ & 8.1 & 7.9 & 7.8 & 8.4 \\
\hline Pancreas proteolytic activity ${ }^{5}(\mathrm{U} / \mathrm{g}$ tissue $)$ at $\mathrm{pH}=6.15$ & 17.5 & 13.2 & 16.7 & 17.3 \\
\hline Pancreas proteolytic activity ${ }^{5}(\mathrm{U} / \mathrm{g}$ tissue) at $\mathrm{pH}=6.75$ & 21.4 & 16.6 & 19.1 & 21.2 \\
\hline Pancreas proteolytic activity ${ }^{5}$ (U/g tissue) at $\mathrm{pH}=7.15$ & 22.7 & 17.6 & 19.5 & 21.7 \\
\hline Pancreas proteolytic activity ${ }^{5}(\mathrm{U} / \mathrm{g}$ tissue) at $\mathrm{pH}=7.50$ & 24.5 & 19.3 & 21.8 & 24.1 \\
\hline Starch hydrolysis $^{6}(\mathrm{~g} / \mathrm{g})$ at $\mathrm{t}=30 \mathrm{~min}$ & 0.274 & 0.279 & 0.281 & 0.295 \\
\hline Starch hydrolysis $^{6}(\mathrm{~g} / \mathrm{g})$ at $\mathrm{t}=1 \mathrm{~h} 00$ & 0.398 & 0.398 & 0.398 & 0.413 \\
\hline Starch hydrolysis $^{6}(\mathrm{~g} / \mathrm{g})$ at $\mathrm{t}=2 \mathrm{~h} 00$ & 0.570 & 0.588 & 0.572 & 0.575 \\
\hline Starch hydrolysis $^{6}(\mathrm{~g} / \mathrm{g})$ at $\mathrm{t}=3 \mathrm{~h} 00$ & 0.663 & 0.698 & 0.689 & 0.676 \\
\hline Starch hydrolysis $^{6}(\mathrm{~g} / \mathrm{g})$ at $\mathrm{t}=4 \mathrm{~h} 00$ & 0.724 & 0.727 & 0.732 & 0.728 \\
\hline
\end{tabular}

${ }^{1}$ One unit (U) was defined as the amount of enzyme which produces an absorbance increase of 0.001 per min at $280 \eta \mathrm{m}$ under the assay conditions (haemoglobin substrate).

${ }^{2}$ One unit (U) was defined as $1 \mu$ mole of tyrosine released per min under the assay conditions (casein substrate).

${ }^{3} 50 \mathrm{mg}$ of pure maize starch hydrolysed with $29.4 \mathrm{mg}$ of pancreas tissue at $\mathrm{pH} 7.4$.

${ }^{4}$ Determined in one proventriculus pool of 6 chickens per treatment. with 2 analytical replicates.

${ }^{5}$ Determined in one pancreas pool of 4 chickens per treatment. with 4 analytical replicates.

${ }^{6}$ Determined in one pancreas pool of 4 chickens per treatment. with 2 analytical replicates. 
Table 4. Body weight (g), proventriculus and pancreas weights $(g)$, and proteolytic enzyme activities in proventriculus ${ }^{l}$ and pancreas $^{2}$ (expressed as U/mg tissue, U/g tissue, or U/g BW) at $27 d$

\begin{tabular}{|c|c|c|c|c|c|c|c|c|}
\hline+8 & \multicolumn{4}{|c|}{ Origin of pools } & \multirow[b]{2}{*}{ SEM } & \multicolumn{3}{|c|}{$P$-value } \\
\hline & $\begin{array}{c}\text { D+ line } \\
\text { (Baltimor fed) }\end{array}$ & $\begin{array}{c}\text { D+ line } \\
(\text { Scipion fed })\end{array}$ & $\begin{array}{c}\text { D- line } \\
\text { (Baltimor fed) }\end{array}$ & $\begin{array}{c}\text { D- line } \\
\text { (Scipion fed })\end{array}$ & & $\begin{array}{l}\text { Line } \\
\text { effect }\end{array}$ & $\begin{array}{l}\text { Diet } \\
\text { effect }\end{array}$ & $\begin{array}{c}\text { Line x Diet } \\
\text { effect }\end{array}$ \\
\hline Mean body weight (g) & 875.7 & 923.2 & 847.0 & 895.8 & $27.87^{3}$ & 0.33 & 0.10 & 0.98 \\
\hline Mean proventriculus weight (g) & 7.16 & 7.13 & 4.19 & 3.95 & $1.341^{3}$ & 0.033 & 0.92 & 0.94 \\
\hline Proventriculus pepsin activity (U/mg tissue $)^{5}$ & 16.5 & 17.5 & 18.3 & 19.2 & & & & \\
\hline Proventriculus pepsin activity $(\mathrm{U} / \mathrm{g} \mathrm{BW})^{5}$ & 134.6 & 134.9 & 90.7 & 84.8 & & & & \\
\hline Mean body weight (g) & 912.5 & 922.5 & 837.0 & 895.8 & $36.61^{4}$ & 0.19 & 0.37 & 0.52 \\
\hline Mean pancreas weight (g) & 1.95 & 1.84 & 2.27 & 1.98 & $0.178^{4}$ & 0.22 & 0.28 & 0.65 \\
\hline Pancreas proteolytic activity (U/g tissue) ${ }^{6}$ & 24.5 & 19.3 & 21.8 & 24.1 & & & & \\
\hline Pancreas proteolytic activity (U/g BW) ${ }^{6}$ & 0.052 & 0.038 & 0.059 & 0.053 & & & & \\
\hline $\begin{array}{l}\text { ne unit }(U) \text { was defined as the amount of enzym } \\
\text { ne unit }(U) \text { was defined as } 1 \mu \text { mole of tyrosine } r \\
\text { ooled standard error for } n=6 \text { replicates. } \\
\text { ooled standard error for } n=4 \text { replicates. } \\
\text { etermined in one proventriculus pool of } 6 \text { chicke } \\
\text { etermined in one pancreas pool of } 4 \text { chickens pe }\end{array}$ & $\begin{array}{l}\text { hich produces } \\
\text { sed per min un } \\
\text { per treatment, } \\
\text { atment, with } 4\end{array}$ & $\begin{array}{l}2 \text { analytical } \\
\text { alytical replic }\end{array}$ & $\begin{array}{l}\text { rrbance of } 0.001 \\
\text { ditions }(\mathrm{pH}=7.5) \\
\text { eplicates. } \\
\text { tes. }\end{array}$ & & & & & \\
\hline
\end{tabular}


Table 5. Gluten (from Baltimor or Scipion wheat cultivar) hydrolyses $(\mathrm{g} / \mathrm{g})$ with proventriculus extract from pools of 6 chickens $\left(\mathrm{pH}=3.0 . \mathrm{T}=40^{\circ} \mathrm{C}\right.$. time $=10$ minutes. Proventriculus proteolytic activity added $=8.3$ U per $\mathrm{mg}$ gluten)

\begin{tabular}{|c|c|c|}
\hline \multirow{2}{*}{$\begin{array}{c}\text { Origin of } \\
\text { proventriculus } \\
\text { extract pool }\end{array}$} & \multicolumn{2}{|c|}{$\begin{array}{c}\text { Wheat cultivar origin } \\
\text { of gluten }\end{array}$} \\
\hline & Baltimor & Scipion \\
\hline $\mathrm{D}^{+}$line (Baltimor fed) & $0.109^{\mathrm{a}}$ & $0.110^{\mathrm{a}}$ \\
\hline $\mathrm{D}^{+}$line (Scipion fed) & $0.103^{\mathrm{a}}$ & $0.105^{\mathrm{a}}$ \\
\hline $\mathrm{D}^{-}$line (Baltimor fed) & $0.113^{\mathrm{a}}$ & $0.121^{\mathrm{a}}$ \\
\hline $\mathrm{D}^{-}$line (Scipion fed) & $0.115^{\mathrm{a}}$ & $0.117^{\mathrm{a}}$ \\
\hline SEM $^{1}$ & 0.0084 & 0.0083 \\
\hline
\end{tabular}


53 Figure 1. Protein hydrolysis of fine (300 to $425 \mu \mathrm{m})$ and coarse (1180 to $1600 \mu \mathrm{m})$ fractions from wheat flours (Baltimor and Scipion) using a proventriculus extract from a pool of 6 chickens $\left(D^{+}\right.$line. Baltimor fed $)\left(p H=3.0 . T=40^{\circ} \mathrm{C}\right.$. Proventriculus proteolytic activity added $=8.3 \mathrm{U}$ per $\mathrm{mg}$ wheat protein) (Mean \pm SEM with 2 analytical replicates).

Protein hydrolysis $(\mathrm{g} / \mathrm{g})$

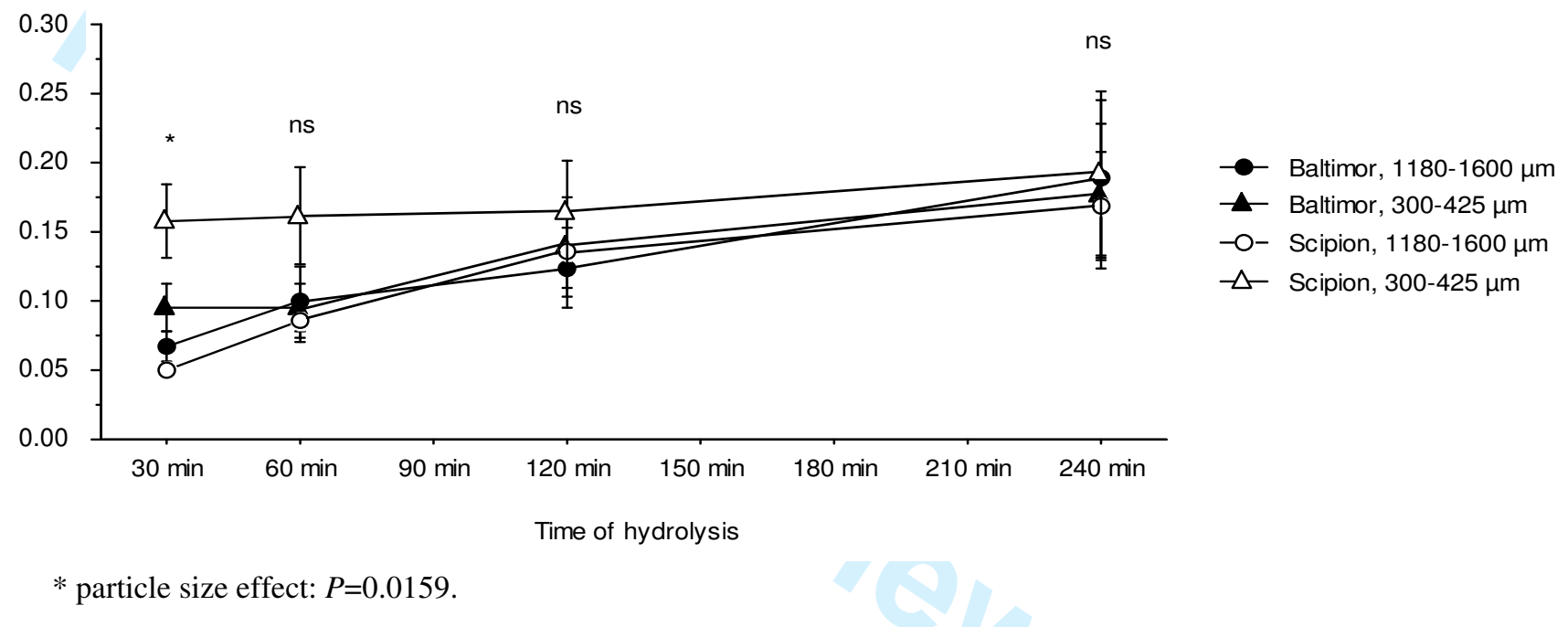

particle size effect: $P=0.0159$ 
1

3

4

5

6

7

8

9

10

11

12

13

14

15

16

17

18

19

20

21

22

23

24

25

26

27

28

29

30

31

32

33

34

35

36

37

38

39

40

41

42

43

44

45

46

47

48

49

50

51

52

53

54

55

56

57

58

59

60
60

61

62

63

\begin{tabular}{|c|c|c|c|c|}
\hline & Baltimor flour & Scipion flour & SEM $^{1}$ & Cultivar effect ${ }^{2}$ \\
\hline Protein hydrolysis $(\mathrm{g} / \mathrm{g})$ & 0.750 & 0.778 & 0.0334 & 0.5711 \\
\hline Starch hydrolysis (g/g) & 0.269 & 0.348 & 0.0031 & $<0.0001$ \\
\hline
\end{tabular}

(gizzard and pancreas steps according to Tervilä-Wilo et al., 1996) on the

Baltimor and Scipion flours. Proventriculus and pancreas enzymatic extracts are from $D^{+}$birds fed on Baltimor wheat 
Table 7. In vivo starch digestibility values ( $\mathrm{g} / \mathrm{g}$ ) (Péron et al., 2006) and laser particle size analysis (spherical volume, v/v) of ileum contents in $D^{+}$and $D^{-}$chicken lines fed with the wheat pelleted diets (942g wheat/kg diet; Baltimor or Scipion cultivar) (means and residual standard deviations)

\begin{tabular}{|c|c|c|c|c|c|c|c|c|}
\hline $\begin{array}{l}\text { Line } \\
\text { Wheat }\end{array}$ & $\begin{array}{c}\mathrm{D}^{+} \\
\text {Baltimor }\end{array}$ & $\begin{array}{c}\mathrm{D}^{+} \\
\text {Scipion }\end{array}$ & $\begin{array}{c}\mathrm{D}^{-} \\
\text {Baltimor }\end{array}$ & $\begin{array}{c}\mathrm{D}^{-} \\
\text {Scipion }\end{array}$ & $\mathrm{RSD}^{1}$ & $\begin{array}{c}\text { Line } \\
\text { Effect }^{2}\end{array}$ & $\begin{array}{c}\text { Diet } \\
\text { Effect }^{2}\end{array}$ & $\begin{array}{l}\text { Line } x \text { Diet } \\
\text { Effect }^{2}\end{array}$ \\
\hline Starch digestibility $(\mathrm{g} / \mathrm{g})(\mathrm{n}=18)$ & 0.906 & 0.967 & 0.881 & 0.935 & 0.0347 & 0.001 & $<0.0001$ & 0.732 \\
\hline $\mathrm{n}$ for particle size analysis & 12 & 11 & 11 & 12 & - & - & - & - \\
\hline Main mode response type $\left(n^{3}\right)$ & 5 & 3 & 3 & 2 & - & - & - & - \\
\hline Bimodal response type $\left(\mathrm{n}^{3}\right)$ & 7 & 8 & 8 & 10 & - & - & - & - \\
\hline Median diameter ${ }^{4}$ of the ileum particles $(\mu \mathrm{m})$ & 233.9 & 198.3 & 222.5 & 158.9 & 109.75 & 0.4369 & 0.1334 & 0.6670 \\
\hline \multicolumn{9}{|l|}{ Main mode response type } \\
\hline Peak position $(\mu \mathrm{m})$ & 362.7 & 416.8 & 457.8 & 553.5 & 93.18 & 0.0622 & 0.2025 & 0.7116 \\
\hline Proportion of particles $(\mathrm{v} / \mathrm{v})$ at peak position & 0.0649 & 0.0627 & 0.0563 & 0.0755 & 0.0113 & 0.7516 & 0.2299 & 0.1392 \\
\hline \multicolumn{9}{|l|}{ Bimodal response type: } \\
\hline Peak 1 position $(\mu \mathrm{m})$ & 20.8 & 18.8 & 20.6 & 18.9 & 0.75 & 0.8186 & $<0.0001$ & 0.6301 \\
\hline Proportion of particles $(\mathrm{v} / \mathrm{v})$ at peak 1 position & 0.0179 & 0.0352 & 0.0260 & 0.0417 & 0.0145 & 0.1597 & 0.0030 & 0.8758 \\
\hline Peak 2 position $(\mu \mathrm{m})$ & 480.8 & 520.1 & 491.1 & 422.6 & 162.78 & 0.4513 & 0.7999 & 0.3538 \\
\hline Proportion of particles $(\mathrm{v} / \mathrm{v})$ at peak 2 position & 0.0554 & 0.0482 & 0.0531 & 0.0472 & 0.0108 & 0.6690 & 0.0947 & 0.8537 \\
\hline $\begin{array}{l}\text { Proportion of particles }(\mathrm{v} / \mathrm{v}) \\
\text { at the small peak position }(17.4 \mu \mathrm{m})^{5}\end{array}$ & 0.0120 & 0.0246 & 0.0186 & 0.0318 & 0.0147 & 0.1208 & 0.0051 & 0.9467 \\
\hline $\begin{array}{l}\text { Proportion of particles }(\mathrm{v} / \mathrm{v}) \\
\text { at the coarse peak position }(478.6 \mu \mathrm{m})^{5}\end{array}$ & 0.0491 & 0.0414 & 0.0470 & 0.0376 & 0.0141 & 0.4819 & 0.0451 & 0.8408 \\
\hline $\begin{array}{l}\text { Residual Standard Deviation. } \\
P \text {-value. } \\
\text { Number of birds. } \\
\text { Half of particles are under this size }(\mu \mathrm{m}) \\
\text { Analysis with all birds (see Figures } 2(\mathrm{a}) \text { and } 2(\mathrm{~b}))\end{array}$ & 2). & & & & & & & \\
\hline
\end{tabular}


Spherical volume $(\mathrm{v} / \mathrm{v})$

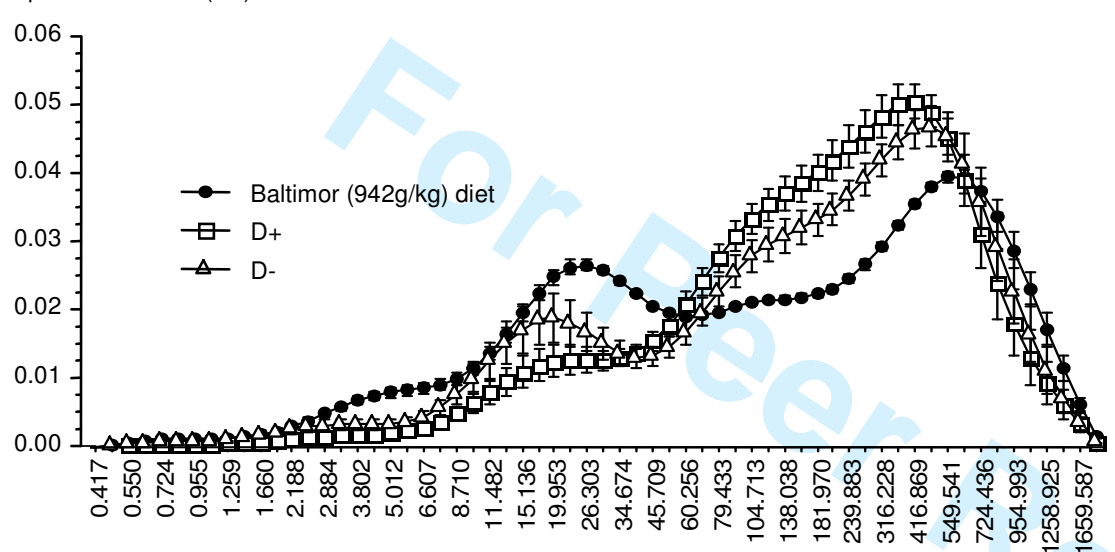

79

$80 \quad$ (b)

Spherical volume (v/v)

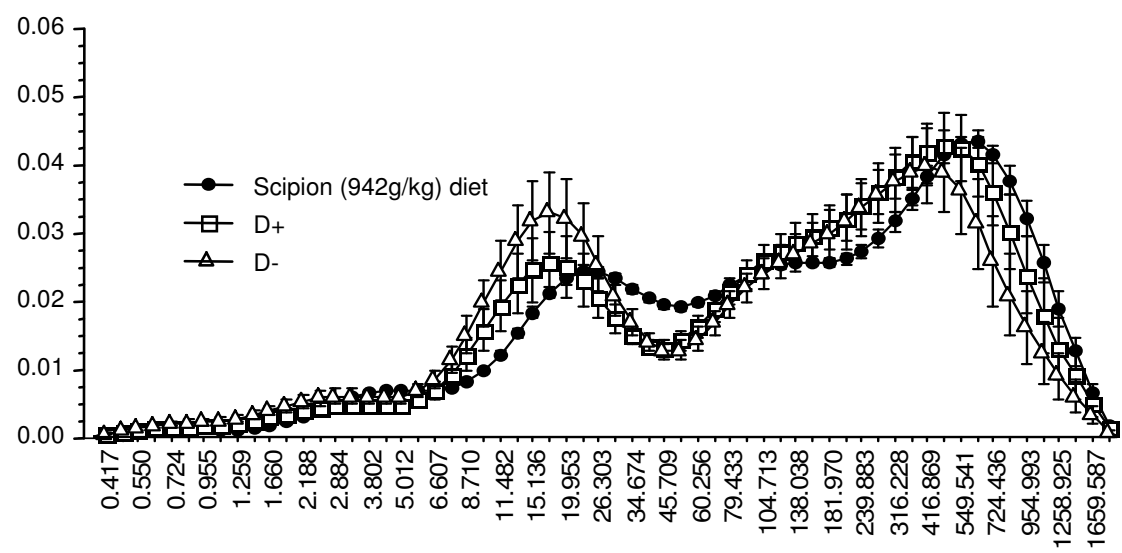

Particle size $(\mu \mathrm{m})$

Particle size $(\mu \mathrm{m})$ chickens fed on these diets (mean \pm SEM. $n=11-12$ ). (a) Baltimor wheat; (b) Scipion wheat.

E-mail: br.poultsci@bbsrc.ac.uk URL: http://mc.manuscriptcentral.com/cbps 
83 Figure 3. Photomicrograph of an ileum content section. observed with bright-field

84

85

86

87 microscopy and analysed with Visilog Software: starch granules (SG). aleurone +bran layer $(A B L)$. example of an analysed subaleurone area (75 $\mu \mathrm{m}$ width) of a bran particle (AREA). 


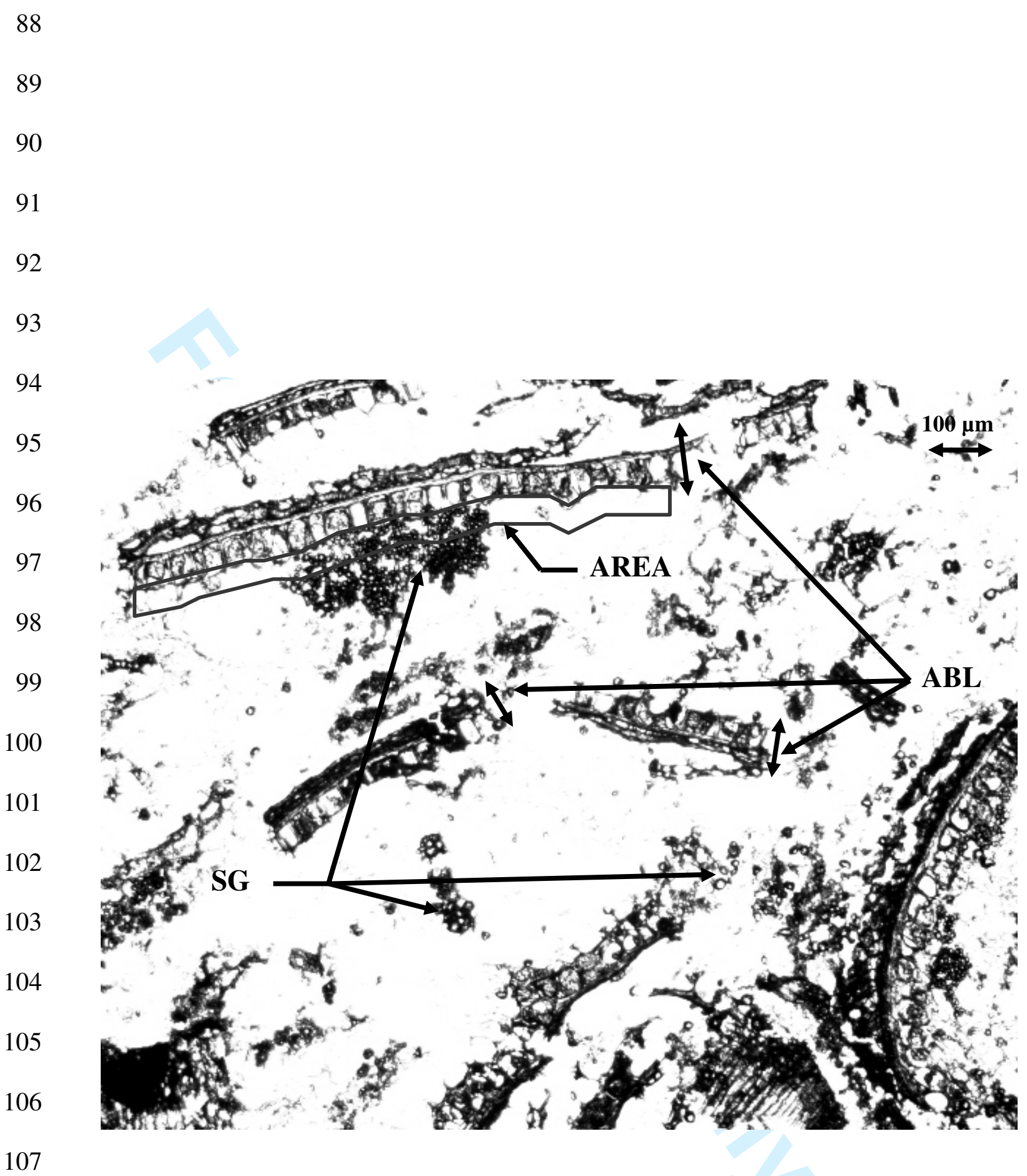


108 Figure 4. Enlarged view of the subaleurone area observed with bright-field 109 microscopy: aleurone cells $(A C)$. starch granules $(S G)$.

110 


\section{1.}

$$
70
$$
की $\mathrm{f}^{\circ}$

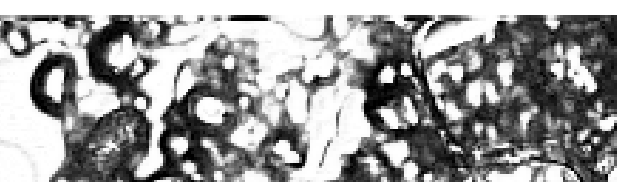
for, $, 0,5$

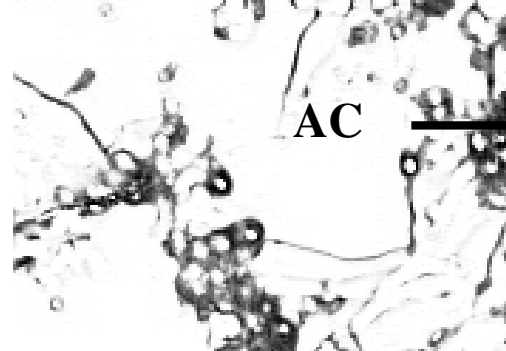

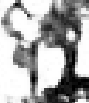

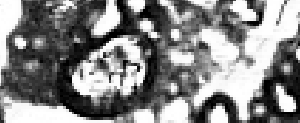
tots 3
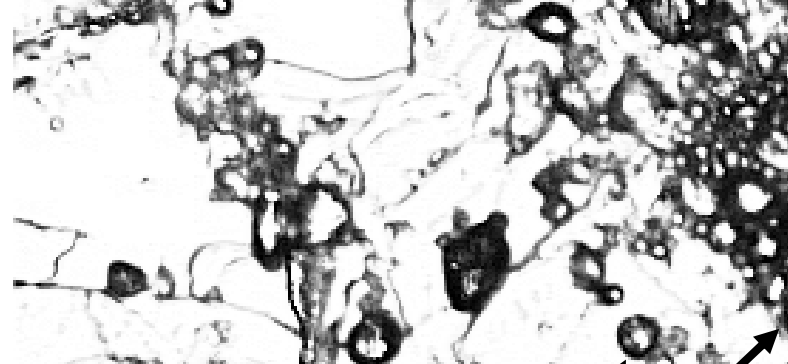
$9.8: 50$ in res.
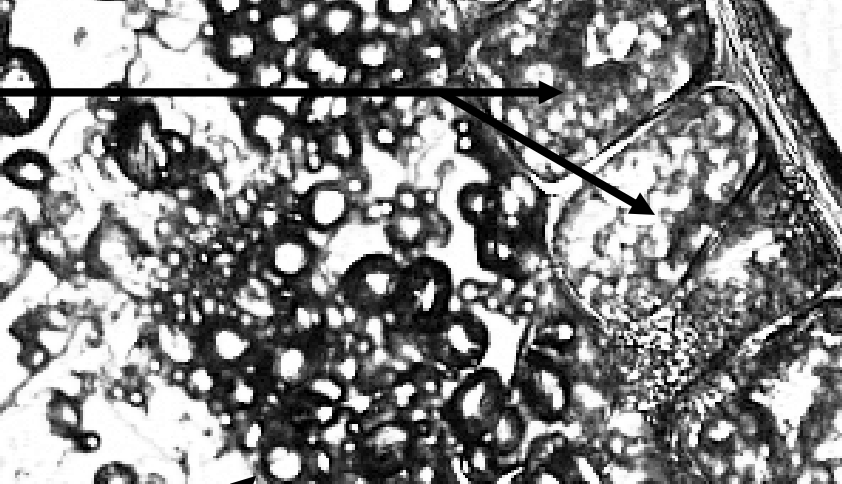
$+8$ .

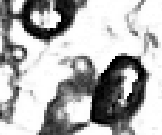
सु

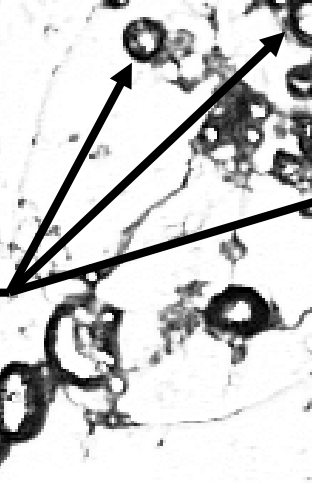

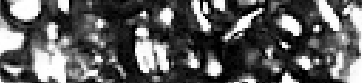


132 Figure 5. Photomicrograph of an ileum content section. observed with fluorescent 133 microscopy: starch granules $(S G)$. endosperm cell walls $(E C W)$.

135 aleurone+bran layer $(A B L)$. 


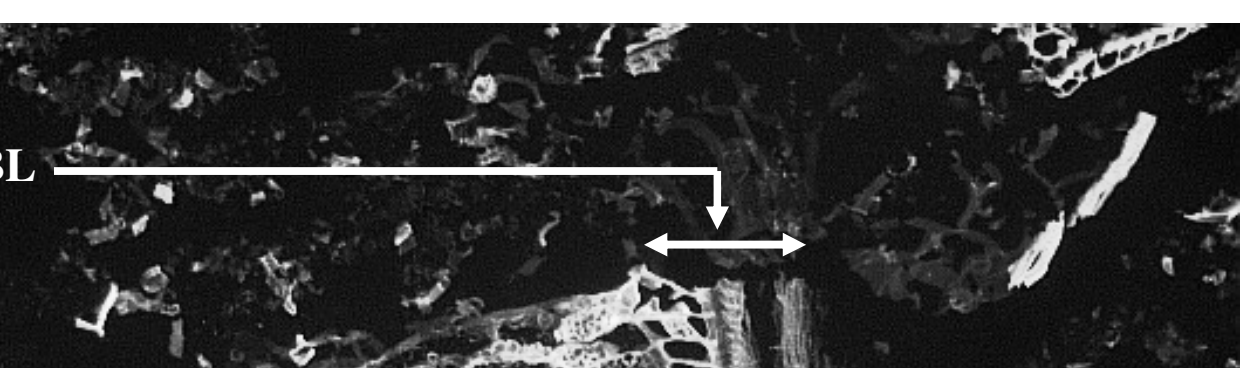


Table 8. Image analyses of bran particles found in ileum contents of $D^{+}$birds fed Baltimor or Scipion diets

\begin{tabular}{lcccc}
\hline & Baltimor & Scipion & RSD $^{1}$ & Cultivar effect $^{2}$ \\
\hline $\begin{array}{l}\text { Lentgh of bran } \\
\text { particles }(\mu \mathrm{m})\end{array}$ & 1043.8 & 936.0 & 433.91 & 0.10 \\
$\begin{array}{l}\text { Estimated starch concentration } \\
\text { in the subaleurone area (OD) }\end{array}$ & 0.361 & 0.231 & 0.1937 & $<0.001$
\end{tabular}

$158{ }^{\mathrm{T}}$ Residual standard deviation $(\mathrm{df}=180)$.

$159{ }^{2} P$-value.

160 OD: Optical density. High values correspond to high starch concentration.

161

162 